\title{
Design and Comparison of Wastewater Treatment Plant Types (Activated Sludge and Membrane Bioreactor), Using GPS-X Simulation Program: Case Study of Tikrit WWTP (Middle Iraq)
}

\author{
Alaa Uldeen Athil Arif*, Mohamed Tarek Sorour, Samia Ahmed Aly \\ Sanitary Engineering Department, Faculty of Engineering, Alexandria University, Alexandria, Egypt \\ Email: *eng91alaa1991@gmail.com
}

How to cite this paper: Arif, A.U.A., Sorour, M.T. and Aly, S.A. (2018) Design and Comparison of Wastewater Treatment Plant Types (Activated Sludge and Membrane Bioreactor), Using GPS-X Simulation Program: Case Study of Tikrit WWTP (Middle Iraq). Journal of Environmental Protection, 9, 636-651.

https://doi.org/10.4236/jep.2018.96040

Received: March 12, 2018

Accepted: May 28, 2018

Published: May 31, 2018

Copyright $(9) 2018$ by authors and Scientific Research Publishing Inc. This work is licensed under the Creative Commons Attribution International License (CC BY 4.0).

http://creativecommons.org/licenses/by/4.0/

\begin{abstract}
Mathematical models and simulation are considered a powerful tool in engineering practice. Those tools are becoming increasingly used for the improvement of wastewater treatment plants design because the conceptual design is complex and ill-defined. In this paper, three alternatives: 1) complete mix activated sludge without nitrogen removal (CAS); 2) complete mix activated sludge with nitrogen removal (CAS-N) and; 3) membrane bioreactor (MBR) processes were designed into two steps: first concept design to calculate the size of process units, then second implement modeling and simulation to improve the accuracy of the conceptual design. In brief, the treatment process design has been verified by using the activated sludge model No. 1 (ASM1) in GPS-X (v.7) simulation software. This application helps not only in sizing the treatment units but also in understanding the plant's capacity. In the same time, it can assist in studying the future expansion works required for increased hydraulic and organic loadings. For this purpose, Tikrit WWTP was selected as a case study. The used model was validated by comparing the designed values of the plant and the modeling data. The verification of the obtained results from both hand calculations and the results of the program showed a good agreement. A significant difference in the volume of secondary treatment was obtained from design calculations, where the CAS without denitrification system was $9244 \mathrm{~m}^{3}$ (aerobic and secondary tanks), CAS with denitrification system was $11,324 \mathrm{~m}^{3}$ (anoxic, aerobic and secondary tanks) and for MBR system was $7468 \mathrm{~m}^{3}$ (anoxic, aerobic and immersed membrane tanks). From the obtained results point of view, it can be concluded that ma-
\end{abstract}


thematical models can be considered as worthy tools to complement the established wastewater treatment plant design procedures.

\section{Keywords}

Activated Sludge, Membrane Bioreactor, Wastewater Treatment, Wastewater treatment Plant Design, Modeling and Simulation

\section{Introduction}

The activated sludge process (ASP) is the most widely used wastewater treatment technology. This is because of its high flexibility which allows the designer to adopt it to any kind of wastewater, it is the most cost effective, and it is also capable of producing high effluent quality that meets the increasingly stringent effluent standards.

In the ASP, microorganisms are responsible for degradation and removal of contaminants within the wastewater [1]. Depending on the design and the specific application, the ASP can achieve biological carbon (C) substances removal and biological nitrogen $(\mathrm{N})$ substances removal [2]. A comprehensive review on evolution of the ASP can be found in the research's Jeppsson [3].

Since the beginning of the 20th century, modifications at the design and operational conditions of the conventional ASP have been developed to meet increasingly stringent performance demands [4]. In this sense, a large number of variations of the conventional ASP have been designed to improve system performance by modifying the reactor layout, influent pattern, aeration system, and operational conditions. Some of the more widely used modified activated sludge processes include completely mixed activated sludge (CMAS), extended aeration activated sludge (EAAS), step-feed activated sludge, oxidation ditch, sequencing batch reactor (SBR), membrane bioreactor (MBR) processes, etc. [5].

Technological development in the last three decades has led to the application of a membrane bioreactor (MBR) for many medium and large municipal WWTPs. MBR is a system that combines biological treatment with membrane filtration into a single process. The first reported application of MBR technology was in 1969, when an ultra-filtration membrane was used to separate activated sludge from the final effluent of a biological wastewater treatment system and the sludge was recycled back into the aeration tank [6]. Since then, the MBR system has evolved, and the research on MBR technology has significantly increased [7]. MBR system used often in countries faced with a barrier of space limitations on one hand, and the increasing expectations regarding effluent quality that sometimes much exceeds those required by legal standards, on the other [8].

The most challenging step in wastewater treatment plant design is the selection of treatment process which defined as a combination of unit operations and processes capable of meeting effluent permit requirements [9]. Usually, design of 
a treatment process is conducted into several steps which mainly include selecting of unit processes (separation and/or reaction including physical, chemical and biological processes) from numerous alternatives, and interconnecting them to create the best process flow diagram to meet predefined performance criteria including effluent permit requirements as well as cost and technical requirements.

Traditionally, design of WWTP's is carried out using empirical equations and simplified system descriptions available in guidelines, for example Metcalf \& Eddy [10], ATV [11], and Park et al. [12]. These guidelines could be used for design purposes by identifying influent wastewater characterizations and operating conditions, and setting the effluent requirements. Accordingly, the treatment plant units are estimated and sized (reactor volume, sedimentation tanks, aeration capacity, pumps capacity, etc.).

Currently, the use of dynamic modeling and simulation is a common practice in the field of wastewater treatment [13]. Many models are available for ASP, such as for degradation of organic carbon material, nitrification and denitrification, and biological phosphorus removal (Activated Sludge Models ASM1, ASM2, and ASM3) [14]. Other models are also available for modifications of activated sludge such as moving bed bioreactors [15], and membrane bioreactors [16]. All these models are supported by several platforms for dynamic simulation of WWTP such as GPS-X, SIMBA, AQUASIM, BioWin, EFOR, STOAT and WEST [2]. Modeling and simulation tools have been used to evaluate process alternatives [17] [18] and [19], to optimize design [20], and to analysis and evaluate costs [21].

Focusing on the design applications, after the preliminary concept design step based on the guidelines, modeling and simulation tool could be used to: 1) evaluate the proposed process alternatives for new WWTP units; 2) check and validate the design in order to confirm different process units sizing, sludge concentrations, recirculation rates, and effluent compliance to the identified standard of discharge limits; and 3) check the performance of the WWTP under dynamic conditions.

The main objective of this paper is to present and demonstrate a systematic approach to design three alternatives of biological wastewater treatment systems, namely conventional activated sludge (CAS1), conventional activated sludge with removal nitrogen (CAS-N) and membrane bioreactor (MBR) for Tikrit, Iraq WWTP as a case study. The design of the three alternatives was conducted into two steps: 1) use the empirical formula and guidelines to initially design the WWTP units, and 2) apply modeling and simulation tool to verify the initial design of the three alternatives using the software GPS-X (v.7).

\section{Material and Methods}

\subsection{Description of the Case Study}

In order of the design requirements for the present study, a WWTP located in 
the area of Tikrit, Iraq was selected as a reference case-study. The WWTP is used to represent the characteristics of municipal wastewater treatment, design population, and the design flow for the plant. The information of this plant was obtained from "ER-GE Design, Engineering, Consulting \& Trade Ltd. Co" report issued in 2013 [22]. This plant was constructed in 1982 with extended aeration system and was designed to treat $20,000 \mathrm{~m}^{3} /$ day of sewage. The characteristics of the influent wastewater in Tikrit WWTP are given in Table 1.

\subsection{Design Methodology}

\subsubsection{Basic Design Data of Preliminary Designs Tikrit WWTP Project}

Designing of wastewater treatment procedure was depended on the characteristics of wastewater, topographic and geographic features in Tikrit city. The estimation amount of both present and projected populations was essential to know the quantity or volume of wastewater in terms of flow. The population that contributes to the treatment plant is that situated inside the design area served by the sewerage system. The construction of WWTP required massive fund investment, so, the design was divide the project into two phases. The planning timeframe of wastewater treatment plant was assumed 39 years from 2018 until 2057 with two phases (Phase I up to 2033 and phase II up to 2057). According to the report [22], the population densities of Tikrit city at 2033 and 2057 with annual increase ratio of $3 \%$ are 182,952 and 371,903 respectively. In order to obtain the daily flow rate from the proposed $200 \mathrm{~L} /$ capita/d water consumption, and $80 \%$ generation from water consumption [22]. Peaking, maximum, and minimum factors equal to $2.75,2$, and 0.3 respectively were selected [10]. There for the values of average, peaking, maximum, and minimum design flow rates were 30,$000 ; 82,500 ; 60,000$; and $90,00 \mathrm{~m}^{3} /$ day respectively for each Phase.

Table 1. Characteristics of domestic wastewaters in Tikrit WWTP.

\begin{tabular}{|c|c|c|c|}
\hline Parameter & Unit & Measured average value & Iraqi standard \\
\hline $\mathrm{PH}$ & - & 7.9 & $6-9.5$ \\
\hline Total suspended solids, SS & $\mathrm{mg} / \mathrm{L}$ & 350 & $<30$ \\
\hline Biological Oxygen Demand, $\mathrm{BOD}_{5}$ & $\mathrm{mg} / \mathrm{L}$ & 320 & $<20$ \\
\hline Chemical Oxygen Demand, COD & $\mathrm{mg} / \mathrm{L}$ & 615.2 & $<60$ \\
\hline Total TKN & $\mathrm{mg} / \mathrm{L}$ & 60 & $<50$ \\
\hline Ammonia Nitrogen, $\mathrm{N}-\mathrm{NH}_{4}$ & $\mathrm{mg} / \mathrm{L}$ & 45 & $<10$ \\
\hline Organic $\mathrm{N}$ & $\mathrm{mg} / \mathrm{L}$ & 15 & - \\
\hline Nitrate Nitrogen, $\mathrm{N}^{-\mathrm{NO}_{3}}$ & $\mathrm{mg} / \mathrm{L}$ & 0 & $<25$ \\
\hline Total P & $\mathrm{mg} / \mathrm{L}$ & 8 & $<3$ \\
\hline $\begin{array}{l}\text { Average wastewater temperature during } \\
\text { summer }\end{array}$ & ${ }^{\circ} \mathrm{C}$ & 25 & $<35$ \\
\hline $\begin{array}{c}\text { Average wastewater temperature during } \\
\text { winter }\end{array}$ & ${ }^{\circ} \mathrm{C}$ & 15 & $<35$ \\
\hline Elevation from mean sea depth & $\mathrm{m}$ & 115 & - \\
\hline
\end{tabular}




\subsubsection{Process Design Description}

In this paper three alternative configurations of the wastewater treatment systems (CAS, CAS-N and MBR) were selected. The design developed for the units of Screen Chamber and Grit Removal Unit for pre-treatment, Primary Clarifier Unit for primary treatment and Anoxic Tank, Aeration Tank, Secondary Clarifier Unit and Membrane Filter Unit for secondary treatment as they are commonly used in the field of wastewater treatment. The designed process was studied and implemented according to various guidelines principles found in the international literature [10] [11] and [12].

Designs for the given guidelines are determined by defining influent wastewater characteristics, specifying operating preferences (e.g. DO and MLSS concentration in the reactors), selecting safety factors (SF) and setting the effluent requirements. The design outcomes will present in the next section.

\subsubsection{Design of Wastewater Treatment Plants (CAS, CAS-N and MBR)}

The design of the WWTPs includes the units of preliminary treatment, primary treatment, and secondary treatment. The preliminary treatment and primary treatment units were assumed the same design sizes for the three studied alternatives (CAS, CAS-N and MBR) because the flow rate was the same value of each alternative. Design and simulation of sludge processing was not included in the overall WWTP model, due to the lack of some relevant data.

\section{1) Preliminary treatment}

Preliminary treatment stage includes two units (coarse screen and grit chamber). The design procedure used in this design stage is described below:

\section{a) Screen chamber}

The screen chamber is provided at the binging of WWTP in order to prevent large particles to pass through. The design details are shown in Table 2.

\section{b) Grit chamber}

Grit chamber is designed to remove grit consisting of sand, gravel, cinders or other heavy solid materials that have subsiding velocities or specific gravities substantially greater than those of the organic putrescible solids in wastewater [10]. The design details are shown in Table 3.

\section{2) Primary treatment}

Table 2. Design details of the screen chamber.

\begin{tabular}{cc}
\hline Parameter \& design criteria* & Equation ${ }^{*} \&$ obtained value \\
\hline Design flow, $Q_{\max }=60,000 \mathrm{~m}^{3} /$ day & Area of screen \\
Approach velocity in the channel, $V_{\mathrm{h}}=0.6 \mathrm{~m} / \mathrm{s}$ & $A_{s}=\frac{Q_{\max }}{V_{h}}=1.5 \mathrm{~m}^{2}$ \\
Depth to width ratio $=1: 1.5$ & Number of bars in the screen: \\
No. of screen in unit at less 2 & $N * t_{\text {bar }}+(N+1) S=W=37$ \\
Clear spacing between bars, $\mathrm{S}=30 \mathrm{~mm}$ & \\
Thick of bar, $t_{\text {bar }}=10 \mathrm{~mm}$ & Head loss $=\frac{1}{C} * \frac{\left(V_{t h}^{2}-V_{h}^{2}\right)}{2 g}=1.4 \mathrm{~mm}$ \\
Coefficient of discharge for clean screen, C $=0.7$ & \\
velocity through screen nars $V_{t h}=0.615 \mathrm{~m} / \mathrm{s}$ &
\end{tabular}

${ }^{*}$ Used according to the source: (Metcalf \& Eddy 2003) [10]. 
Table 3. Design details of the grit chamber.

\begin{tabular}{cc}
\hline Parameter \& design criteria* & Equation* \& obtained value \\
\hline Design flow, $Q_{\text {peak }}=82,500 \mathrm{~m}^{3} /$ day & Volume of each tank \\
No. of grit chamber in unit $=2$ & $=Q_{\text {peak }} *$ D.T $/ 2=86 \mathrm{~m}^{3}$ \\
Detention time, D.T $=3 \mathrm{~min}$ & Width $=3.6 \mathrm{~m}$ \\
Depth: width $=1: 1.2$ & Length $=8 \mathrm{~m}$ \\
Depth $=3 \mathrm{~m}$ & total Air Requirement $=4.8 \mathrm{~m}^{3} / \mathrm{min}$ \\
The air-supply requirement $=0.3 \mathrm{~m}^{3} / \mathrm{min} / \mathrm{m}$ & Total volume of grit $=0.45 \mathrm{~m}^{3} / \mathrm{d}$ \\
Quantity of grit to be removed $=0.015 \mathrm{~m}^{3} / 10^{3} \mathrm{~m}^{3}$ at $Q_{\text {ave }}$ & \\
* Used according to the source: (ATV-DVWK 2000) [11]. &
\end{tabular}

In primary treatment the wastewater still contains non-coarse suspended solids (settleable solids and part of the organic matter), which can be partially removed in sedimentation units. Primary clarifier unit represents the primary treatment stage. Table 4 presents the design details of primary clarifier.

\section{3) Secondary treatment}

The wastewater will be allowed for biological treatment in the secondary treatment process which includes three different systems configuration:

a) Carbonaceous removal process (CAS)

In this system, only carbonaceous matter is removed by microorganisms in the reactor (aerobic tank). The computation approach for the design of the activated-sludge process is presented in Table 5.

b) Crbonaceous, nitrification and denitrification removal process (CAS-N).

This system is designed for the removal of both carbonaceous and nitrogenous substance by microorganisms in the reactor (anoxic and aerobic tank). The computation approach for the design of the ASP is shown in Table 6.

\section{c) Secondary clarifier design}

As part of the proposed secondary treatment for (CAS and CAS-N), a secondary clarifier is designed. The secondary clarifier is essential for the removal of suspended solids that encompass the nutrients. The computation approach for the design of the secondary clarifier is shown in Table 7 .

d) Carbonaceous, nitrification and denitrification removal process with immerged membrane

The computation third approach for the design of nitrification and de-nitrification tanks was same that used in design alternative two (activated sludge with biological nitrogen removal). The design criteria of nitrification and de-nitrification tanks were also same except MLVSS and SRT were used 8000 $\mathrm{mg} / \mathrm{l}$ and 20 days respectively. The computation approach for the design was found $\mathrm{Se}=0.73 \mathrm{mg} / \mathrm{l}$,

$$
\begin{gathered}
p_{x, b i o}=1842 \frac{\mathrm{kg}}{\mathrm{d}}, P_{x, T}=2839 \mathrm{~kg} / \mathrm{d}, \\
V=6218 \mathrm{~m}^{3}, V_{\text {anox }}=1250 \mathrm{~m}^{3}, X_{\text {anox }}=2114 \mathrm{mg} / \mathrm{l}, \\
\frac{F}{M_{\text {anox }}}=3.5 \mathrm{~d}^{-d} \text { and capacity ratio }=1.13 .
\end{gathered}
$$


Table 4. Design details of primary clarifier.

\begin{tabular}{cc}
\hline Parameter \& design criteria* & Equation* \& obtained value \\
\hline $\begin{array}{c}\text { Design flow, } Q_{\text {ave }}=30,000 \mathrm{~m}^{3} / \text { day } \\
\text { Surface loading rate, } \mathrm{SLR}=40 \mathrm{~m}^{3} / \mathrm{m}^{2} \cdot \mathrm{d}\end{array}$ & Area $(A)=\frac{Q}{\mathrm{SLR}}=750 \mathrm{~m}^{2}$ \\
No. of Primary sedimentation tank $=2$ & Diameter: $D=\sqrt{\frac{4 A}{\pi}}=22 \mathrm{~m}$ \\
Depth $=3 \mathrm{~m}$ & Weir loading rate, WLR $=217 \mathrm{~m}^{3} / \mathrm{m} . \mathrm{d}$ \\
Empirical constants, a, b: $0.018,0.020$ for BOD & expected removal efficiency, \\
$0.0075,0.014$ for TSS & $R=\frac{t}{a+b . t}=33.5 \%$ BOD, $55.3 \%$ TSS \\
\hline
\end{tabular}

*Used according to the source: (Metcalf \& Eddy 2003) [10].

Table 5. Design detail of carbonaceous removal process (CAS).

\begin{tabular}{|c|c|}
\hline Parameter \& design criteria ${ }^{*}$ & Equation ${ }^{*} \&$ obtained value \\
\hline $\begin{array}{c}\mathrm{BOD}_{5} / \mathrm{BOD}_{\mathrm{u}}=0.666 \% \\
\mathrm{BOD}_{\mathrm{u}} / X_{b}=1.42 \% \\
\text { Desired effluent SS }=25 \mathrm{mg} / \mathrm{l}\end{array}$ & $S_{s s}=\frac{\mathrm{BOD}_{5}}{\mathrm{BOD}_{\mathrm{u}}} *\left[\frac{\mathrm{BOD}_{\mathrm{u}}}{X_{b}} * S S_{b} / S S_{e}\right]=15.4 \mathrm{mg} / 1$ \\
\hline $\begin{array}{c}\text { Biodegradable fraction (generating solids) }=0.65 \\
\text { Desired effluent BOD }=20 \mathrm{mg} / \mathrm{l}\end{array}$ & $S_{\mathrm{sol}}=S_{\text {total }}-S_{\mathrm{ss}}=4.6 \mathrm{mg} / 1$ \\
\hline $\begin{array}{c}\text { Sludge age, } \theta_{c}=10 \text { days } \\
S_{0}=212.8 \mathrm{mg} / 1 \\
\text { Yield coefficient, } Y=0.5 \\
\text { MLVSS concentration }=3500 \mathrm{mg} / 1 \\
\text { Endogenous respiration coefficient, } \\
K_{d}=0.057 \mathrm{~d}^{-1} \text { at }\left(15^{\circ} \mathrm{C}\right)\end{array}$ & $V=\frac{Y \theta_{c} Q_{a v e}\left(S_{o}-S_{s o l}\right)}{\operatorname{MLVSS}\left(1+K_{d} \theta_{c}\right)}=5,684 \mathrm{~m}^{3}$ \\
\hline $\begin{array}{c}\text { Return sludge ratio } Q_{I} / \mathrm{Q}=0.8 \\
\text { Concentration of recycle sludge, } X r=10,000 \mathrm{mg} / \mathrm{l}\end{array}$ & $\begin{array}{c}\theta_{c}=\frac{V * X}{\left(Q_{W} * X_{r}\right)+\left(Q_{e} * X_{e}\right)} \\
\rightarrow \text { sludge waste rate, } Q_{W}=174 \mathrm{~m}^{3} / d\end{array}$ \\
\hline Hydraulic detention time, $\mathrm{HRT}=V /(Q)=0.19 d$ & $\frac{F}{M}=\frac{S_{0}}{\mathrm{HRT} * \mathrm{MLVSS}}=0.32 d^{-1}$ \\
\hline
\end{tabular}

*Used according to the source: (Metcalf \& Eddy 2003; ATV-DVWK 2000) [10] [11].

\section{e) Membrane system}

The design of the membrane system includes determining the design flux, the required number of membrane modules, and the aeration requirement for coarse bubble aeration. Table 8 presents design criteria of membrane system.

\subsection{Verification of the Design Guideline Using Mathematical Modeling}

A computer program GPS-X (v.7) software package (Hydromantis Inc., Ontario, Canada) was used in this study to verify and optimize the obtained plants design. It was also used to simulate and verify the process performance in normal condition and shock loading conditions (double organic load and increase of influent flow). The predicted effluent concentrations obtained with the process model are then compared to the effluent requirements which were imposed for the designs. These enable to investigate whether the guidelines lead to optimal designs or to over- or under-sized plants. It is important to stress that the same criteria used 
Table 6. Design detail of carbonaceous, nitrification and denitrification removal process (CAS-N).

\begin{tabular}{|c|c|}
\hline Parameter \& design criteria ${ }^{*}$ & Equation $* \&$ obtained value \\
\hline $\begin{array}{c}\text { Sludge age, } \theta \mathrm{c}=10 \text { days } \\
\text { Half-saturation coefficient: } \mathrm{Ks}=20 \mathrm{mg} / 1 \\
\text { maximum specific growth rate, } \mathrm{m}=4.28 \mathrm{~d}^{-1} \\
\text { Endogenous respiration coefficient, } \\
K d=0.1 \mathrm{~d}^{-1} \text { at }\left(15^{\circ} \mathrm{C}\right)\end{array}$ & $\begin{aligned} \text { Effluent COD, } S= & \frac{K_{S}\left(1+K_{d} \mathrm{SRT}\right)}{\operatorname{SRT}\left(m-K_{d}\right)-1} \\
& =1 m g \mathrm{COD} / l\end{aligned}$ \\
\hline $\begin{array}{c}\text { Design flow, Qave }=30,000 \mathrm{~m}^{3} / \mathrm{day} \\
\text { biodegradable COD, bCOD }=1.6 \times \mathrm{BOD}=340 \mathrm{mg} / \mathrm{l} \\
\text { oxidizable ammonia concentration, } N O_{x}=49.3 \mathrm{mg} / \mathrm{l} \\
\text { yield coefficient, } Y=0.5 \\
\text { growth yield of nitrifying bacteria, } y n=0.12 \\
\text { decay constant of nitrifying bacteria, } \\
\text { Kdn }\left(15^{\circ} \mathrm{C}\right)=0.065 \mathrm{~d}^{-1} \\
\text { fraction of biomass accumulated during decay, } \\
\qquad d=0.15 \\
\text { inert material in influent wastewater, } \\
X_{o, i}=21.5 \mathrm{mg} / \mathrm{l}\end{array}$ & $\begin{array}{c}\text { solids production, } \\
p_{x, b i o} \frac{Q Y\left(S_{o}-S\right)}{1+\left(k_{d}\right) \mathrm{SRT}}+\frac{Q y_{n} N O_{x}}{1+\left(k_{d n}\right) \mathrm{SRT}}+f_{d} k_{d} \\
\frac{Q Y\left(S_{o}-S\right)}{1+\left(k_{d}\right) \mathrm{SRT}} \mathrm{SRT}=2443.5 \mathrm{~kg} / \mathrm{d} \\
\text { total solids, } P_{\mathrm{x}, \mathrm{T}} \\
P_{x, T}=p_{x, b i o}+Q X_{o, i}=3088.5 \mathrm{~kg} / \mathrm{d}\end{array}$ \\
\hline $\begin{array}{c}\text { MLVSS concentration }=3500 \mathrm{mg} / \mathrm{l} \\
\text { H.D.T }=2 \mathrm{~h}\end{array}$ & $\begin{array}{c}V=\frac{P_{x, T}}{\mathrm{MLVSS}}=8824 \mathrm{~m}^{3} \\
V_{\text {anox }}=\mathrm{H} . \mathrm{D} . \mathrm{T} * Q_{\text {ave }} / 24=2500 \mathrm{~m}^{3}\end{array}$ \\
\hline $\begin{array}{c}\text { Effluent nitrate concentration, } N O_{e}=25 \mathrm{mg} / 1 \\
\text { recycle nitrate }=N O_{x}-N O_{e}=24.3 \mathrm{mg} / l \\
\qquad I R=N O x / N O r-1=1.03 \\
\text { based on Metcalf \& Eddy SDNR }=0.35 \mathrm{~g} / \mathrm{g} \cdot \mathrm{d}\left(15^{\circ}\right)= \\
0.31\end{array}$ & $\begin{array}{c}X_{\text {anox }}=\frac{Q * S R T}{V_{\text {era }}} * \frac{Y\left(S_{o}-S\right)}{1+\left(k_{d}\right) S R T} \\
* \frac{I R}{I R+1}=1170 \mathrm{mg} / \mathrm{l} \\
\frac{F}{M_{\text {anox }}}=\frac{Q S_{o}}{V_{\text {anox }} X_{\text {anox }}}=3.5 \mathrm{~d}^{-1} \\
\text { Nox feed }=Q * I R * N O_{r}=751 \mathrm{~kg} / \mathrm{d} \\
\text { NOr reduce }=V_{\text {anox }} * \mathrm{SDNR} * X_{\text {anox }} \\
=907 \mathrm{~kg} / \mathrm{d}\end{array}$ \\
\hline $\begin{array}{l}\text { Return sludge ratio } Q_{r} / Q=0.8 \\
\text { concentration of recycle sludge, } \\
\qquad X r=10,000 \mathrm{mg} / 1\end{array}$ & $\begin{array}{c}\theta_{c}=\frac{V * X}{\left(Q_{W} * X_{r}\right)+\left(Q_{e} * X_{e}\right)} \\
\text { sludge waste rate, } Q_{W}=311 \mathrm{~m}^{3} / \mathrm{d}\end{array}$ \\
\hline
\end{tabular}

${ }^{\star}$ Used according to the source: (Metcalf \& Eddy 2003) [10].

Table 7. Design detail of secondary clarifier.

\begin{tabular}{cc}
\hline Parameter \& design criteria* & Equation* \& obtained value \\
\hline $\begin{array}{c}\text { Design flow, } Q_{\text {ave }}=30,000 \mathrm{~m}^{3} / \mathrm{day} \\
\text { Surface loading rate, } \mathrm{SLR}=16 \mathrm{~m}^{3} / \mathrm{m}^{2} \cdot \mathrm{d}\end{array}$ & $\operatorname{Area}(A)=\frac{Q}{\mathrm{SLR}}=1875 \mathrm{~m}^{2}$ \\
No. of Primary sedimentation tank $=2$ & Diameter: $D=\sqrt{\frac{4 A}{\pi}}=35 \mathrm{~m}$ \\
Depth $=3.7 \mathrm{~m}$ & Weir loading rate, WLR $=375 \mathrm{~m}^{3} / \mathrm{m} \cdot \mathrm{d}$ \\
\hline
\end{tabular}

${ }^{\star}$ Used according to the source: (Metcalf \& Eddy 2003; ATV-DVWK 2000) [10] [11]. 
Table 8. Design detail of membrane system.

\begin{tabular}{|c|c|}
\hline $\begin{array}{c}\text { Parameter \& design } \\
\text { criteria }^{*}\end{array}$ & Equation* \& obtained value \\
\hline $\begin{array}{l}\text { Maximum operating } \\
\text { flux }=40 \mathrm{~L} / \mathrm{m}^{2} \cdot \mathrm{h}\end{array}$ & Desion flux $=\frac{(\text { Maximum operating flux })(\text { Filtration ratio })(\text { Operating ratio })}{}$ \\
\hline Filtration ratio $=0.968$ & Peaking factor \\
\hline $\begin{aligned} \text { Operating ratio } & =0.988 \\
\text { Peaking factor } & =2.75\end{aligned}$ & $=14 \mathrm{~L} / \mathrm{m}^{2} \cdot \mathrm{h}$ \\
\hline $\begin{array}{l}\text { Membrane area per } \\
\text { module }=31.6 \\
\mathrm{~m}^{2} / \text { module }\end{array}$ & $\begin{aligned} \text { Number of modules }= & \frac{\text { Daily average flow }}{(\text { Design flux })(\text { Membrane area per module })} \\
& =2826 \text { modules }\end{aligned}$ \\
\hline $\begin{array}{c}\text { Membrane } \\
\text { area }=89301.6 \mathrm{~m}^{2} \\
\mathrm{SAD}_{\mathrm{m}}=0.54 \mathrm{~m}^{3} / \mathrm{m}^{2} \cdot \mathrm{h} \\
\text { Filtration }=900 \mathrm{sec} \\
\text { Backwash }=30 \mathrm{sec}\end{array}$ & $\begin{array}{c}\text { coarse bubble aeration } \\
Q_{A, m}=\left(\mathrm{SAD}_{m}\right)(\text { Membrane area }) \frac{\text { filteration time }}{\text { cycle time }}=46,667 \frac{\mathrm{m}^{3}}{\mathrm{~h}}\end{array}$ \\
\hline $\begin{array}{l}\text { Membrane packing } \\
\text { density }=45 \mathrm{~m}^{2} / \mathrm{m}^{3}\end{array}$ & $V_{m}=\frac{A_{m}}{\text { packing density }}=1985 \mathrm{~m}^{3}$ \\
\hline
\end{tabular}

${ }^{\star}$ Used according to the source: (Park et al. 2015) [12].

for the design requirements are applied in the evaluation step.

In order to carry out the WWTPs simulation, the same inputs used for the designs (influent characteristics and operating preferences together with the design outcomes obtained from the guideline are used to develop the process model. The major models used to evaluate the designs WWTPs includes mainly the Activated Sludge Model No. 1 (ASM1) for biological processes, the BOD based influent model for influent characterization, and the model simple1d for clarification process [23].

Daily average value of influent flow rate, influent concentrations [Biological Oxygen Demand (BODin), Total suspended solids (Xin), and Total Kjeldahl Nitrogen (TKNin)] were used as inputs for the model and Mixed Liquor Suspended Solids in the aeration tank (MLSSr). The value of DO concentration was set at $2 \mathrm{mg} / \mathrm{L}$ for oxygen transfer efficiency of the fine bubble diffusers. Figure 1 represents the layouts of the designed WWTPs that used for simulation of the three alternatives.

\section{Discussion of Differences Observed}

In order to verify the design results for the WWTPs (CAS, CAS-N and MBR), the adjustment of some operational parameters have to be taken into account. Steady-state simulation provides a solution to the system based on the average influent flow to the system. Those parameters were adjusted one by one until the model fits well. Table 9 represents values before and after adjustment.

In order to understand the differences obtained between some values before and after model calibration several factors have to be taken into account: 1) In fact, the design allows selecting two important characteristics of the treatment plant: the MLSS and the SRT. However, it is impossible to impose both on the dynamic process model. When imposing an MLSS concentration, the BSM1 
Table 9. Modifications in some parameters were obtained by using GPS-X for WWTPs.

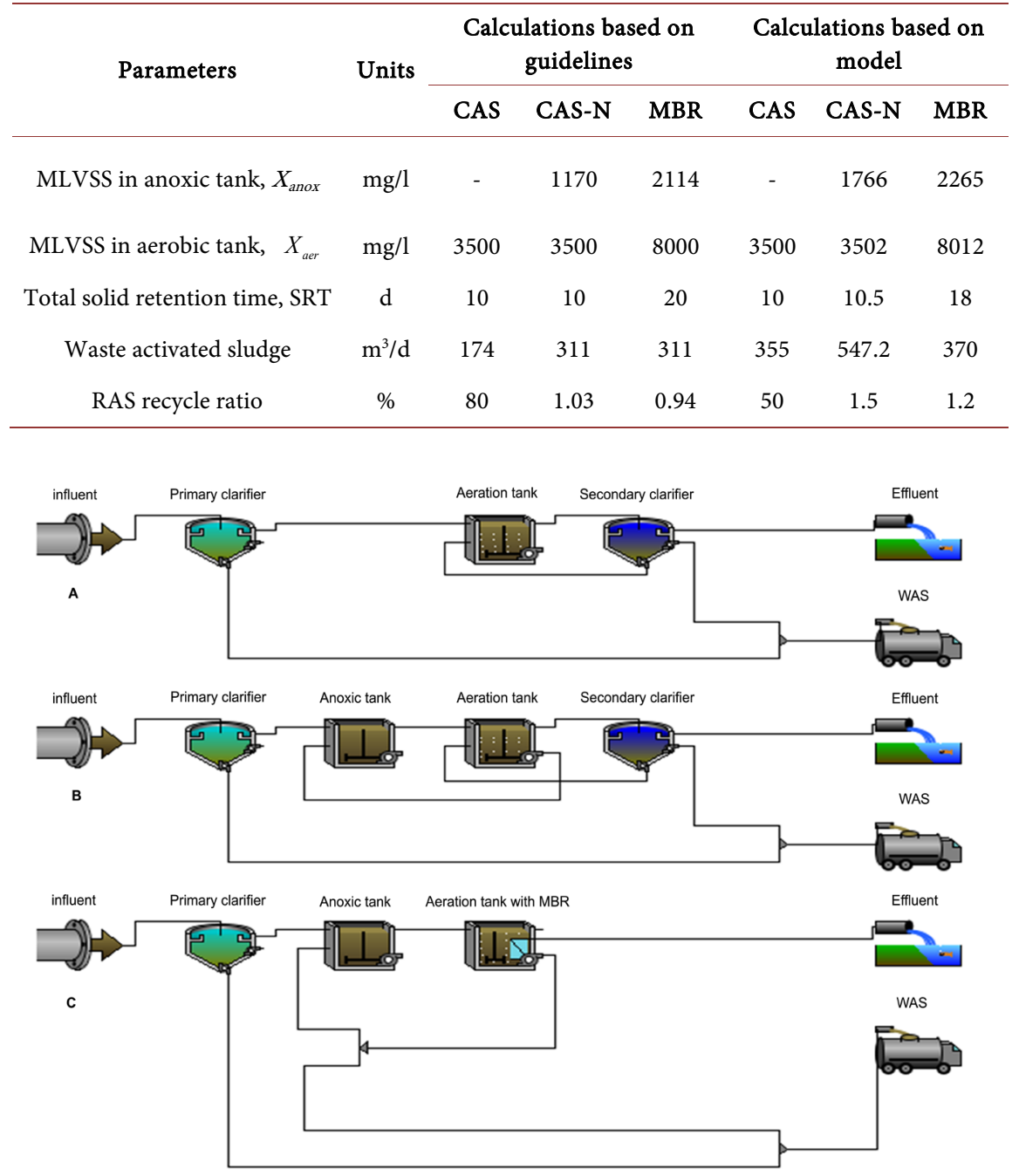

Figure1. WWTPs layout used in GPS-X software: (A) Compete mix activated sludge without denitrifications; (B) Compete mix activated sludge with denitrifications; (C) Compete mix activated sludge with denitrifications and membrane bio reactor.

simulations result in change the SRTs. The differences in the SRTs can be explained by the different model structures of both models that do not allow fixing the MLSS and the SRT of the system at the same time. Note that, when fixing the SRTs (and leaving the MLSS to evolve to lower values) would make that the effluent organic compounds concentrations would come higher and closer to the values the plant was designed for. 2) Sludge production is much higher after modeling compared to the expected sludge production from the hand calculations. The different between default kinetic and stoichiometric parameters for both the used guidelines and model structure, may lead to those differences [24].

\section{Results and Discussion}

The results and discussion part is divided into two parts. The first part deals with the empirical design of the wastewater treatment plants, while the second one 
deals with the application of modeling and simulation tool to verify the initial design WWTPs using GPS-X (v.7).

\subsection{Designs Obtained with the Empirical Formula and Guidelines}

Table 10 shows the footprint variation of each stage given by the empirical formula and the guidelines to initially design the WWTP units. It was noted that there was a significant difference in the volumes of the bioreactors, where it was $9244 \mathrm{~m}^{3}$ for the CAS without denitrification system (aerobic and secondary tanks), 11,324 $\mathrm{m}^{3}$ for the CAS with denitrification system (anoxic, aerobic and secondary tanks) and $7468 \mathrm{~m}^{3}$ for the MBR system (anoxic, aerobic and immerged membrane tanks).

The MBR has the lowest volume compared to CAS processes due to use an immerged membrane in the aeration tanks with surface area equals $89,302 \mathrm{~m}^{2}$. The membrane is used as a filter instead of gravity sedimentation tanks, which results in a smaller footprint than CAS processes.

\subsection{Evaluation of Designs with a Dynamic Process Model}

The second goal of this study is to verify the design guideline with ASM1-based process model. Verification processes were implemented through the examination of the process unit's sizes by means of the performance of CAS, CAS-N and MBR under two scenarios (stable and unstable conditions) to ensure the accuracy of the plants to reach the design effluent requirements.

\subsubsection{Performance of WWTPs at Stable Condition}

In this stage, the analysis was prepared based on the steady state performance. To assess the performance of each system to remove organic matter, the flow rate was kept constant at $30,000 \mathrm{~m}^{3} / \mathrm{d}$ and the domestic wastewater characteristics of Tikrit WWTP is the same as given in Table 1. Figure 2 represent an example of agreement between the model and the process performance. It can be noted that, as shown in Figure 2, higher removal efficiencies of the organic matter were achieved by each system under the normal conditions. In addition to effluent concentrations in each system still enough to meet Iraqi code requirements.

Table 10. Summarized of a footprint of each stage for all alternatives (CAS, CAS-N, and MBR).

\begin{tabular}{cccccc}
\hline \multirow{2}{*}{ The units included of each stage } & Units & \multicolumn{3}{c}{ Footprint required of each stage } \\
\cline { 5 - 6 } & Screen chamber & $\mathrm{m}^{2}$ & 1.5 & 1.5 & 1.5 \\
\hline \multirow{2}{*}{ Preliminary treatment } & Grit chamber & $\mathrm{m}^{3}$ & 172 & 172 & 172 \\
\multirow{2}{*}{ primary treatment } & Primary clarifier & $\mathrm{m}^{3}$ & 2250 & 2,250 & 2250 \\
& Anoxic tank & $\mathrm{m}^{3}$ & - & 2500 & 1250 \\
\multirow{2}{*}{ Secondary treatment } & Aerobic tank & $\mathrm{m}^{3}$ & 5684 & 8824 & 6218 \\
& secondary clarifier & $\mathrm{m}^{3}$ & 6937 & 6937 & - \\
\hline
\end{tabular}




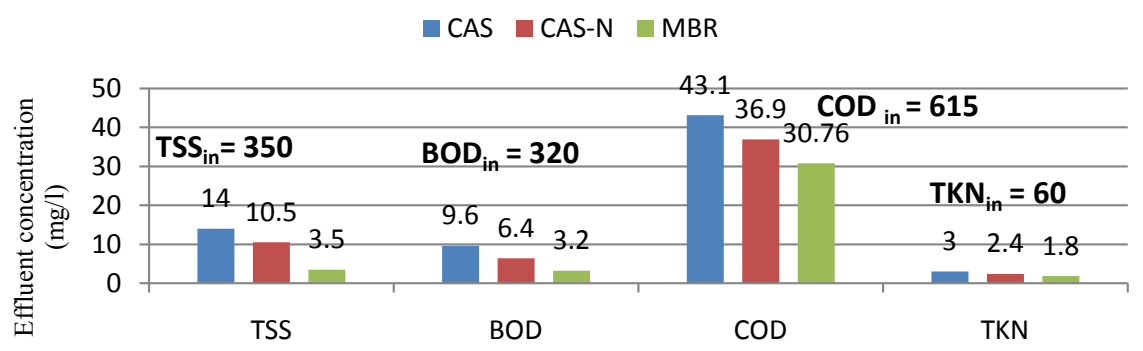

Figure 2. Effluent concentrations for CAS, CAS-N and MBR under stable condition.

\subsubsection{Performance of WWTPs under Unstable Conditions}

The conditions at any wastewater treatment process are usually altered due to the change in flow-rate and composition of wastewater with the time. The unstable conditions lead to complexity in the operation of the activated sludge processes, which requires accurate and well developed modeling techniques. In order to assess the changed conditions on the performance of WWTP, two scenarios were investigated.

The aim of the first scenario is to investigate the performance of the three processes under a hydraulic shock load. So, the flow rate was increased from $20,000 \mathrm{~m}^{3} / \mathrm{d}$ to $60,000 \mathrm{~m}^{3} / \mathrm{d}$. Figure 3 represents the effluent values of TSS, BOD, COD and TKN under the hydraulic shock load. However, the results showed a decrease in the removal efficiency of the examined parameters (TSS, BOD, COD and TKN), the design of Tikrit WWTPs is still worked with good efficiency to meet Iraqi code requirements.

The aim of the second scenario is to investigate the performance of the three processes under an organic shock load. The flow rate was kept constant at 30,000 $\mathrm{m}^{3} /$ day for CAS, CAS-N and MBR. While, the double of the influent organic load was used (TSS $=700 \mathrm{mg} / \mathrm{l}, \mathrm{BOD}=640 \mathrm{mg} / \mathrm{l}, \mathrm{COD}=1,208 \mathrm{mg} / \mathrm{l}$ and $\mathrm{TKN}=$ $120 \mathrm{mg} / \mathrm{l})$. Results represented in Figure 4 showed a higher ability of the three WWTP processes (CAS, CAS-N, and MPR) to sustain the change in the organic loads. The effluent concentrations were still accepted according to Iraqi code (TSS $<30 \mathrm{mg} / \mathrm{l}),(\mathrm{COD}<60 \mathrm{mg} / \mathrm{l}),($ BOD $5<20 \mathrm{mg} / \mathrm{l})$ and $(\mathrm{TKN}<60 \mathrm{mg} / \mathrm{l})$. It can be also noted from Figure 4 that the lowest effluent concentrations of the examined parameters were obtained by The MBR process.

After the application of those scenarios, good simulation results were obtained to assure the reliability of the program in the running of different scenarios. Therefore it can be demonstrated that the empirical design is fruitful, and the sizes of the process units achieve the requirements of Iraqi code.

\subsection{Evaluation of the Design Guideline Verification Methodology}

BSM1 simulations can be used to study the change of the reactor volume. The volume can be reduced until the predicted effluent concentrations reach the design effluent requirements. In this case the dynamic simulations are applied with gradual changes in the volume of the aerobic reactors. The results represented in Figure 5 shows that the used design guidelines give over-sized aerobic reactors 


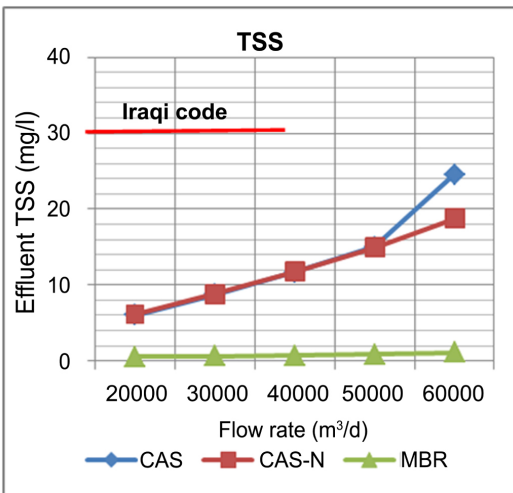

(a)

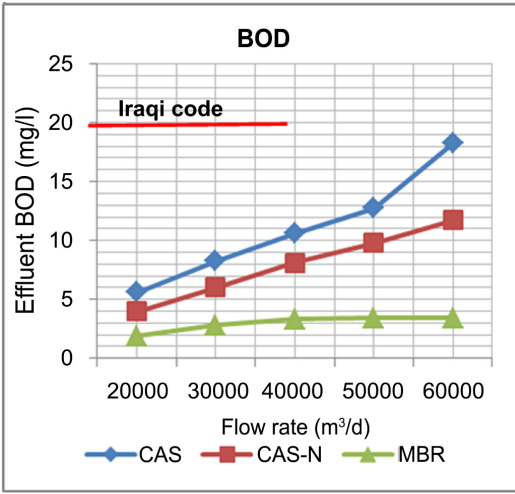

(c)

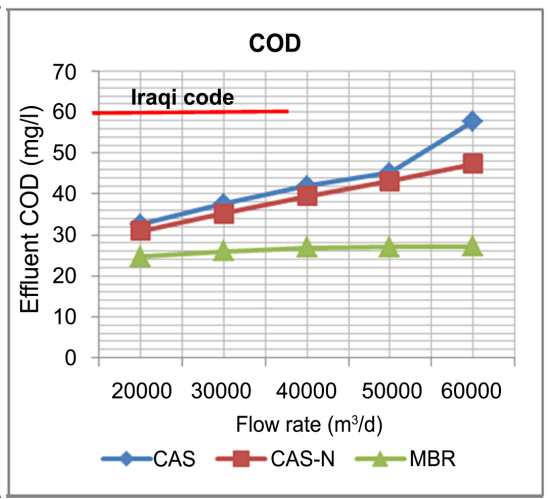

(b)

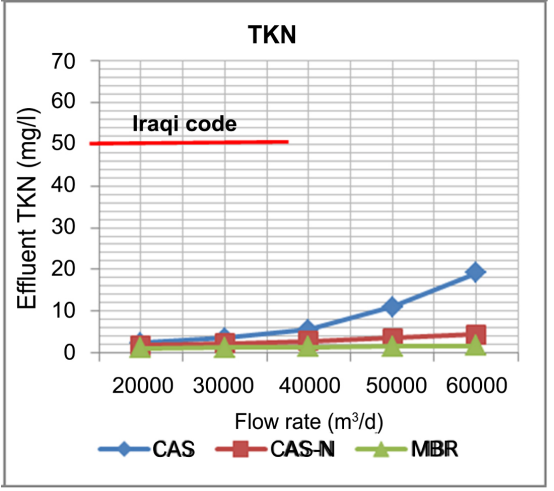

(d)

Figure 3. Effluent concentrations of (a) TSS; (b) COD; (c) BOD; and (d) TKN at different influent flows.

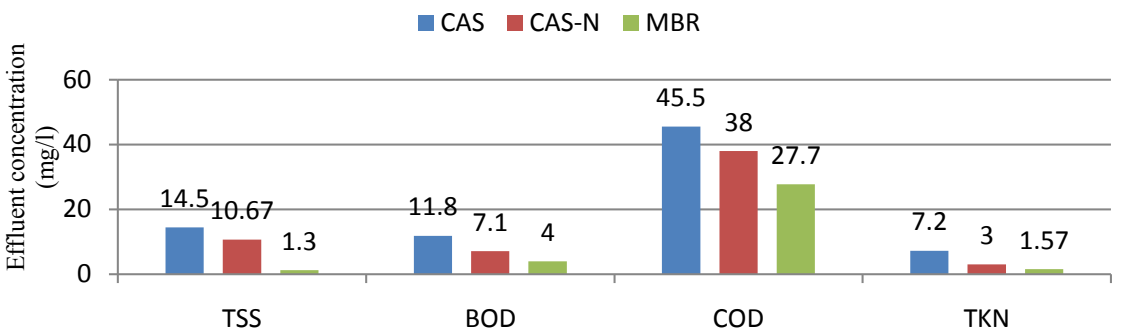

Figure 4. Performance of CAS, CAS-N and MBR under organic shock load.

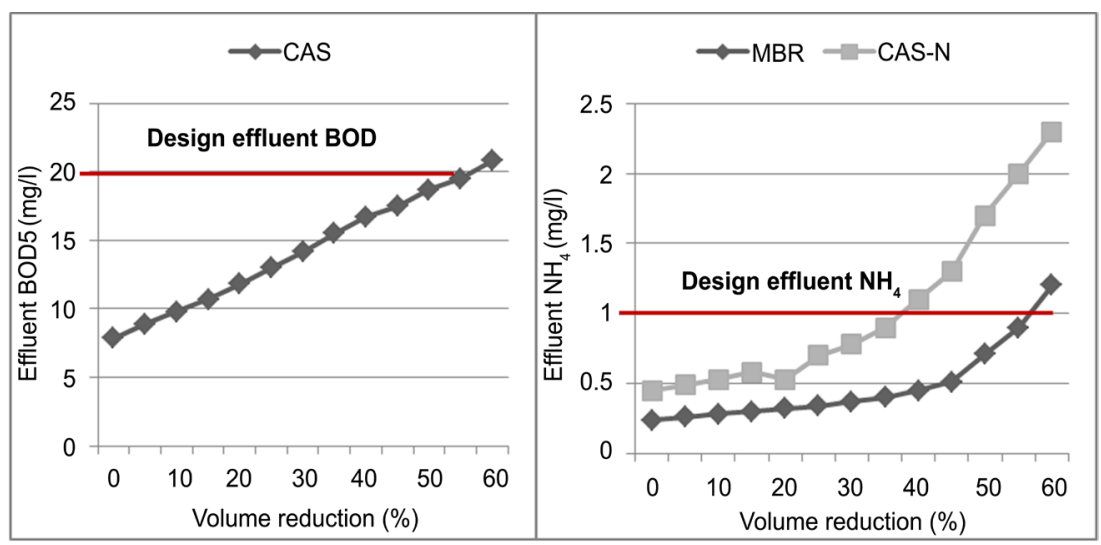

Figure 5. Predicted effluent BOD5 and $\mathrm{NH}_{4}$ at different volume reductions (at $Q_{\text {ave }}=3000 \mathrm{~m}^{3} / \mathrm{d}$ ). 
compared to the BSM1 simulations. This may be due to the differences in the model structure and their default model parameters [24]. Therefore; the aerobic volume could be reduced by 55\% for CAS, 35\% for CAS-N, and 55\% for MBR according to the ASM-type model.

The plant size can be significantly reduced if the safety margins included in the dimensioning guidelines is removed. In Benedetti et al. [25] the volumes obtained with ATV design guidelines were reduced up to $60 \%$ of its original volume when using a dynamic model. Also, in Corominas et al. [24] the volumes obtained with Metcalf \& Eddy design guidelines were reduced up to $35 \%$ of its original volume when using a dynamic model.

\section{Conclusion}

The present study set out to design three configurations of WWTPs and verify the designed process by the application of GPS-X model. From the methodology of conceptual design described in this paper, results illustrated that proper design construction combined with good produce effluents can be developed to support optimal treatment process selection. In general, using application of GPS-X is very helpful tool in verifying the pre-design of WWTPs. In addition, this application helps in understanding the plant's performance under different conditions as well as in deciding the future expansion works needed for increased hydraulic and organic loadings. It can be concluded that the verification of design guidelines is not easy issue and there is still further work to do, however, both design guidelines and dynamic process model simulations have their role to play and to make better understanding of the impact of various factors of the process design.

\section{References}

[1] Sixgh, G. and Dhir, A. (2012) Computer Aided Process Designing of Sewage Treatment Plant with Activated Sludge Process. Master Thesis, Dept. of Biotecirnology and Enironmental Sciences, Thapar University, Punjab.

[2] Gernaey, K.V., van Loosdrecht, M.C.M., Henze, M., Lind, M. and Jørgensen, S.B. (2004) Activated Sludge Wastewater Treatment Plant Modeling and Simulation: State of the Art. Environmental Modelling \& Software, 19, 763-783. https://doi.org/10.1016/j.envsoft.2003.03.005

[3] Jeppsson, U. (1996) Modelling Aspects of Wastewater Treatment Processes. PhD Thesis, IEA, Lund Institute of Technology, Lund.

[4] Henze, M., van Loosdrecht, M.C.M., Ekama, G. and Brdjanovic, D. (2008) Biological Wastewater Treatment Principles, Modelling and Design. IWA Publishing, Glasgow.

[5] Evans, R.W. (2012) Implementing an Improved Activated Sludge Model into Modeling Software. MS Thesis, Environmental Systems Engineering, University of Regina.

[6] Smith, C.W., Gregorio, D. and Taleott, R.M. (2009) The Use of Ultrafiltration Membrane for Activated Sludge Separation. 24th Annual Purdue Industrial Waste Conference, Purdue University, 6-9 May 1969, 1300-1310. 
[7] Yang, W., Cicek, N. and Ilg, J. (2006) State-of-the-Art of Membrane Bioreactors: Worldwide Research and Commercial Applications in North America. Journal of Membrane Science, 270, 201-211. https://doi.org/10.1016/j.memsci.2005.07.010

[8] Directive of the Minister of Environment of Republic of Poland of 24 July 2006 on Conditions to Be Met When Discharging Effluent to Water or to Soil and on Substances Especially Harmful to Water Environment. Dz.U.06.137.984., Changed Dz.U.09.27.169., Warsaw, Poland.

[9] Tchobanoglous, G., Burton, F.L. and Stensel, H.D. (2003) Wastewater Engineering: Treatment and Reuse. McGraw-Hill Publishing, New York.

[10] Metcalf and Eddy (1991) Wastewater Engineering, Treatment, Disposal, Reuse. 3rd Edition, McGraw-Hill, Inc., New York.

[11] ATV-DVWK (2000) ATV-DVWK Standards A 131E, Dimensioning of Single-Stage Activated Sludge Plants, ATV-DVWK, Water, Wastewater, Waste, Hennef, Germany.

[12] Park, H.D., Chang, L.S. and Lee, K.J. (2015) Principles of Membrane Bioreactors for Wastewater Treatment. CRC Press, New York, U.S.

[13] Copp, J.B., Johnson, B.R., Shaw, A., Burbano, M.S., Narayanan, B., Frank, K., Kinnear, D., Melcer, H. and Brischke, K. (2009) A Balancing Act: The Consulting Engineers' Pragmatic View of Process Modelling. Water Science \& Technology, 59, 763-769. https://doi.org/10.2166/wst.2009.594

[14] Henze, M., Gujer, W., Mino, T. and van Loosdrecht, M. (2000) Activated Sludge Models ASMI, ASM2. ASM2d and ASM3, IWA Publishing, London, England.

[15] Mannina, G., Di Trapani, D., Viviani, G. and Odegaard, H. (2011) Modelling and Dynamic Simulation of Hybrid Moving Bed Biofilm Reactors: Model Concepts and Application to a Pilot Plant. Biochemical Engineering Journal, 56, 23-36. https://doi.org/10.1016/j.bej.2011.04.013

[16] Zuthi, M.F.R., Guo, W.S., Ngo, H.H., Nghiem, L.D. and Hai, F.I. (2013) Enhanced Biological Phosphorus Removal and Its Modelling for the Activated Sludge and Membrane Bioreactor Processes. Bioresource Technology, 139, 363-374. https://doi.org/10.1016/j.biortech.2013.04.038

[17] Daigger, G.T. and Nolasco, D. (1995) Evaluation and Design of Full-Scale Wastewater Treatment Plants Using Biological Process Models. Water Science \& Technology, 31, 245-255. https://doi.org/10.2166/wst.1995.0112

[18] Hao, X., van Loosdrecht, M.C.M., Meijer, S.C.F. and Qian, Y. (2001) Model-Based Evaluation of Two BNR Processes-UCT and A2N. Water Research, 35, 1-2860. https://doi.org/10.1016/S0043-1354(00)00596-0

[19] Larrea, L., Albizuri, J., Irizar, I. and Hernandez, J.M. (2007) Design and Operation of SBR Processes for Small Plants Based on Simulations. Water Science \& Technology, 55, 163-171.

[20] Rivas, A., Irizar, I. and Ayesa, E. (2008) Model-Based Optimisation of Wastewater Treatment Plants Design. Environmental Modelling \& Software, 23, 435-450. https://doi.org/10.1016/j.envsoft.2007.06.009

[21] Vanrolleghem, P.A., Jeppsson, U., Carstensen, J., Carlsson, B. and Olsson, G. (1996) Integration of Wastewater Treatment Plant Design and Operation-A Systematic Approach Using Cost Functions. Water Science \& Technology, 34, 159-171. https://doi.org/10.2166/wst.1996.0429

[22] ER-GE Design, Engineering, Consulting, Trade Ltd. Co. (2013) Preliminary Report Is Prepared to Design Tikrit Wastewater Treatment Plant in Tikrit, Iraq. 
[23] Takács, I., Patry, G.G. and Nolasco, D. (1991) A Dynamic Model of the Clarification-Thickening Process. Water Research, 25, 1263-1271. https://doi.org/10.1016/0043-1354(91)90066-Y

[24] Flores-Alsina, X. Corominas, L., Muschalla, D., Neumann, M.B. and Vanrolleghem, P.A. (2010) Verification of WWTP Design Guidelines with Activated Sludge Process Models. Proceedings: IWA World Water Congress and Exhibition, Montréal, 19-24 September 2010, 137-146.

[25] Benedetti, L., De Keyser, W., Nopens, I. and Vanrolleghem, P.A. (2010) Probabilistic Modelling and Evaluation of Wastewater Treatment Plant Upgrades in a Water Quality Based Evaluation Context. Journal of Hydroinformatics, 12, 380-395.

https://doi.org/10.2166/hydro.2010.011 